\title{
Henryk Kuna and Tymon Niesiołowski - New Trends in the Artistic Culture of Vilnius in the 1930s
}

\section{Swietłana Czerwonnaja}

Uniwersytet Mikołaja Kopernika w Toruniu

In the 1930s, the painter Tymon Niesiołowski and the sculptor Henryk Kuna were considered the most striking figures in the fine arts field in Vilnius. They were tied together not only by the bonds of creative consolidation, but also by personal friendship. Their work, as well as their pedagogical activity in the Department of Fine Arts of Stephen Bathory University, contributed, one might say, to the "late revival of the avant-garde" that took place in the artistic culture of Vilnius in the 1930s.

Keywords: Vilnius art school, "belated avant-garde" of the 1930s, artistic life in Vilnius (Polish Wilno) and in Kaunas. 


\section{Personal relationship between Kuna and Niesiołowski}

In the 1930s, the painter Tymon Niesiołowski and the sculptor Henryk Kuna were considered the most striking figures in the fine arts field in Vilnius. They were tied together not only by the bonds of creative consolidation, but also by personal friendship.

The roots of the spiritual kinship that existed between them began in the Paris school - not in a particular academy or art institute, but in the widely understood École de Paris of the early 20th century. For many artists from Eastern Europe (including both Polish and Lithuanian) l'École de Paris was the spiritual alma mater, the only great school of that artistic avant-garde which began its triumphal march from Paris to the rest of Europe.

Kuna first visited Paris in 1903 (ten years earlier than Niesiołowski) and, as his biographer Mieczysław Wallis writes, he was fascinated by the works of the great sculptor Rodin ${ }^{1}$, and was captured by this charm. He returned to Paris again in 1911 ("to study sculpture again"2), and finally ended up there, in this case for 6 years between 1924 and 1930 when he lived and worked in Paris.

Niesiołowski, a graduate of the Krakow Academy of Arts (19001905), went to Paris for several months in 1913. He did not meet Kuna there, because Kuna had returned to Poland from his second trip to Paris in 1912. Nevertheless, contact with the art of the avant-garde in l'École de Paris greatly influenced the further creativity of both. The formation in Poland of the art group "Rhythm", to which Henryk Kuna, Wacław Borowski, Eugeniusz Zak and Tymon Niesiołowski belonged (they were called "Rhythmists-classics"3) - as the art historian Henryk Anders, who studied the "classical direction" in the Polish art avant-garde movement, was one of the first to notice, - was due to the ideas which the young Polish artists were exposed to in Paris in 1910-1914.

1 Wystawa rzeźb Henryka Kuny 1879-1945, wrzesień-październik 1956, [The Exhibition of Henryk Kuna's sculpture. September-October 1956], (Katalog opracował Dariusz Kaczmarek, autor artykułu wstępnego Mieczysław Wallis / Ed. Dariusz Kaczmarek, Mieczysław Wallis - author of the introductory article), [Warszawa]: Związek Polskich Artystów Plastyków, Centralne biuro wystaw artystycznych, 1956 , p. 5 .

2 Ibid., p. 6.

3 Jan Żyznowski, "Zachęta. Wystawa Rytmu" [Zahęta. The Exhibition of Rhythm], in: Wiadomości literackie, No. 21, 1924, p. 5.

4 Henryk Anders, Rytm. W poszukiwaniu stylu narodowego [Rhythm. Looking for a national style], Warszawa, 1972, p. 55-56. 
Much is written in the literature on the topic of the life, creativity, development trends and the style of Kuna's sculpture and Niesiołowski's painting. The main conclusions of which concern their common ideals, attempts to reinterpret the ancient heritage, and even more so analysis of individual works, does not make sense (as there is no physical possibility) as set out in this paper.

I would like however, to draw your attention to the personal relationship that existed between Kuna and Niesiołowski because this relationship is often ignored, forgotten or unknown by researchers.

If Niesiołowski and Kuna did not meet for the first time in Vilnius (no doubt they had known each other before), then undoubtedly it was in Vilnius that they became particularly close to each other and it was in Vilnius that they developed their mutual creative and personal relationship.

It seems that genuine friendship, empathy and mutual understanding connected Niesiołowski with Henryk Kuna (among the professors of the Department of Fine Arts of Stephen Báthory University). He happily recalled Kuna's arrival at the fishing village of Chalupa, where Niesiołowski spent his summer vacations, in $1937^{5}$. They worked together to organise the reporting exhibition of the Department of Fine Arts of Stephen Báthory University (SBU) in $1938^{6}$.

Do not forget that Niesiołowski (a painter according to God's will!) was also engaged in sculpture. To what extent Kuna, as a sculptor, could have influenced both the sculptural works of Niesiołowski created before World War II (Dorota's Head, 1938; monument carved in stone for Aunt Anna Dzipkowska, 1939-1940) and after the war (Torso, 1947; Standing Nude, 1947; Reclining Nude, 1947-1948; - both in patinated plaster; Torso, 1954-1955, wood), - is not really clear. A more interesting task is to compare the sculptural works of Kuna with Niesiołowski's paintings. And it is not a matter of finding sculptural motives in the picturesque still lifes of

5 Tymon Niesiołowski, Wspomnienia [Memoirs], Warszawa: Czytelnik, 1963, p. 113.

6 They stand next to each other in a photograph taken during the grand opening of this exhibition. See: Tymon Niesiołowski (1882-1965): Katalog wystawy monograficznej [Tymon Niesiołowski (1882-1965): The catalogue of the personal exhibition], Ed. Agata Rissman, Torun: Muzeum Okręgowy, 2005, p. 41). Dr Małgorzata Gieroń found and published this photograph in her article included in this catalogue: Małgorzata Gieroń, "Kalendarium życia i twórczości Tymona Niesiołowskiego" [Calendar of the life and creativity of Tymon Niesiołowski], in: Tymon Niesiołowski (1882-1965): Katalog wystawy monograficznej [Tymon Niesiołowski (1882-1965): The catalogue of the personal exhibition], Ed. Agata Rissman, Toruń: Muzeum Okręgowy, 2005, pp. 13-54. 


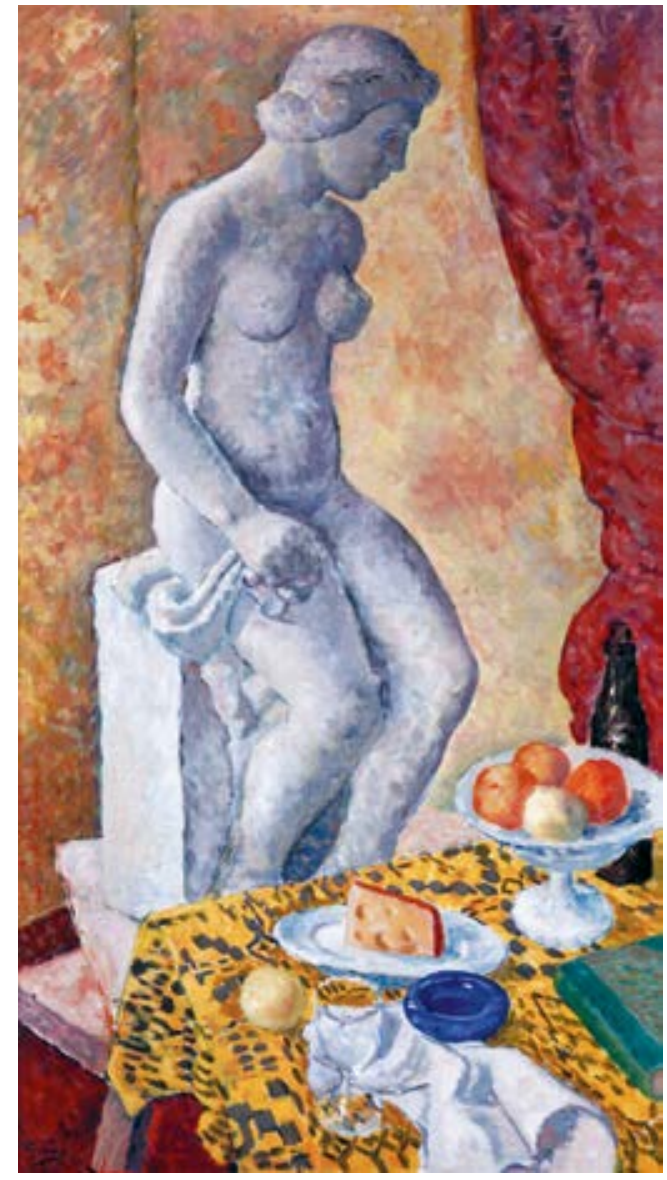

Tymon Niesiołowski, Still Life with a Sculpture, 1939, canvas, oil, National Museum in Warsaw

Tymonas Niesiołowskis,

Natiurmortas su skulptūra, 1939

Niesiołowski (an example is his Still Life with a Sculpture, 1939, [illus. 1]). I was not able to identify this sculpture - the image of a seated woman with any well-known work of Kuna, but there is an undoubted resemblance of this image to the sculptural works of Kuna [illus. 2]. A more important task is to identify stylistic similarities, spiritual "kinship" between pictorial images of Niesiołowski [illus. 3, 4] and sculptural works of Kuna [illus. 5, 6]. The artistic and humanistic concept of human itself; the place that a person occupies in space; interpretation of the human body, its beauty, freedom of movement; the appeal to ancient, Greek motifs and ideals and the attempts to bring them closer to the rhythms and laconic constructions of cubism - all 
formed the creative world, where Kuna and Niesiołowski had something in common - similar, although not exactly the same.

Niesiołowski, as an artist, greatly appreciated the art of Kuna and was always ready to provide Kuna with moral support. He reacted sharply to the persecution to which Kuna was subjected in Vilnius. He wrote in his Memoirs about the situation in 1930s': "At that time, antipathy towards the Jews and their persecution intensified. Not even Henryk Kuna was spared this. There were people who did not want to allow his monument to Mickiewicz to be erected in this city, because they, blind in their nationalist madness, denied him the right to be a Pole."

In 1945, it was none other than Niesiołowski who managed to bring the already terminally ill Kuna by boat, across the Vistula River to Torun, where together they participated in the foundation of the Department of Fine Arts at the new University - named after Nicolaus Copernicus.

This page of history concerns the post-war period, but it is so little known that I allow myself to tell about these events of 1945 , supplementing the biographies of Niesiołowski and Kuna with material gathered in the Archive of Nicolaus Copernicus University. Kuna, who lived in Warsaw permanently, was not among the citizens who were to be repatriated from Lithuania to Poland and did not end up on that famous train that arrived in Torun from Vilnius in the spring of 1945. The train brought a large group of former professors, assistants and graduates of Stephen Báthory University, and it is they to whom credit must be given for founding Nicolaus Copernicus University, which was to a large extent modelled and based on the traditions of the Stephen Báthory University. Without Kuna, however, the chair of sculpture at the new University seemed unthinkable, since the greatest achievements of the chair of sculpture of the former SBU were associated with both his name and his leadership. Henryk Kuna received an official invitation (which Niesiołowski had a significant part in generating) to take up the position of professor and head of the chair of sculpture of the University of Nicolaus Copernicus (UNC (UMK)). In response to this invitation, Kuna wrote in a letter addressed to the Dean of the Faculty of Humanism on 3 October 1945: "I would be honoured to be part of the community of professors at this University".

7 Tymon Niesiotowski, p. 114.

8 Archiwum UMK, K1/8 (Henryk Kuna, Acta osobowe). (There are no numbers of folios and pages in the documentation of this Archive, only the numbers of personal folders of teachers). 


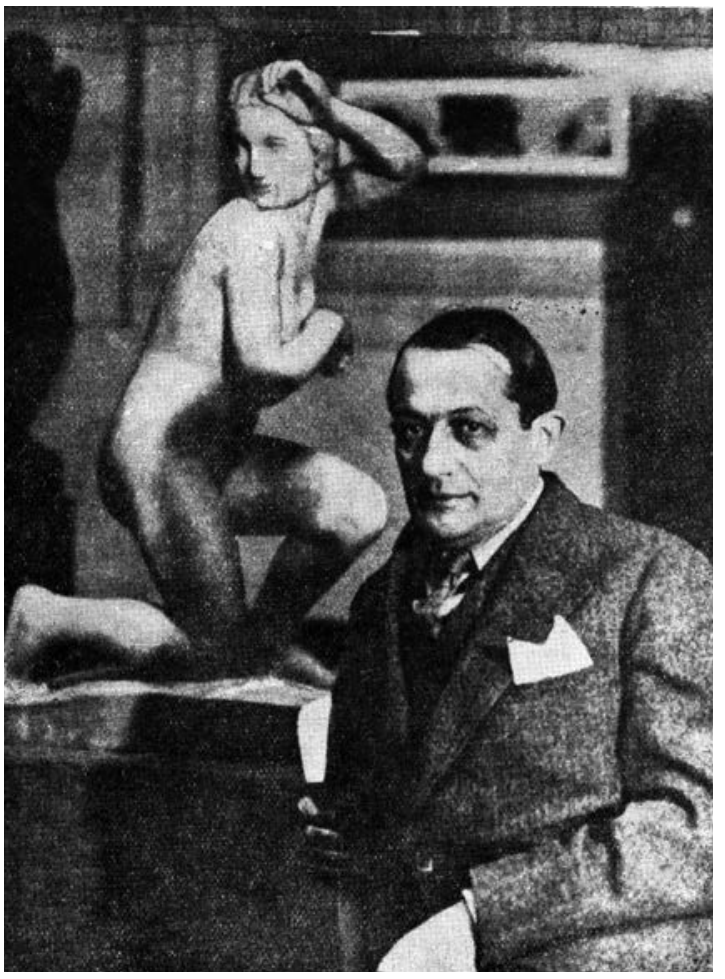

2.

Henryk Kuna in his workshop in Warsaw near his work - a sculptural image of a naked woman, 1930s, Photograph in the Documentation Department of the National Museum in Warsaw Henrykas Kuna Varšuvos dirbtuvèje šalia savo kūrinio nuogos moters skulptūros, $\mathrm{XX}$ a. 4 deš.

Unfortunately, Kuna's time at Nicolaus Copernicus University was short-lived, as he died on 17 December $1945^{\circ}$. During the war and Nazi occupation, he was forced to hide from the Germans. He was tormented by anxiety about the fate of his only son, who was badly wounded in the September 1939 military campaign and ended up in German captivity. A year later, his son was released from the prisoner of war camp because he was in such bad health. He returned to Poland, where he recovered from his wounds and became a member of the resistance movement; he died in the Warsaw Uprising on 5 August 1944, (a fact which his parents only learnt about much later). In the years 1940-1943, Kuna hid from the invaders in the small town of Świder near Warsaw and then hid in his Warsaw apartment on Red Cross Street. Completely isolated from people, he led an almost prison lifestyle there. After the suppression of the Warsaw uprising, he was

9 Ibid. Notation 17. XII, 1945 (Archiwum UMK, F. K1/8). This should be noted, since Lithuanian public opinion after the war spread the misconception that Kuna was a victim of the Holocaust and died during the war (from an interview recorded by the author in 1961 with the sculptor Juozas Mikènas). 


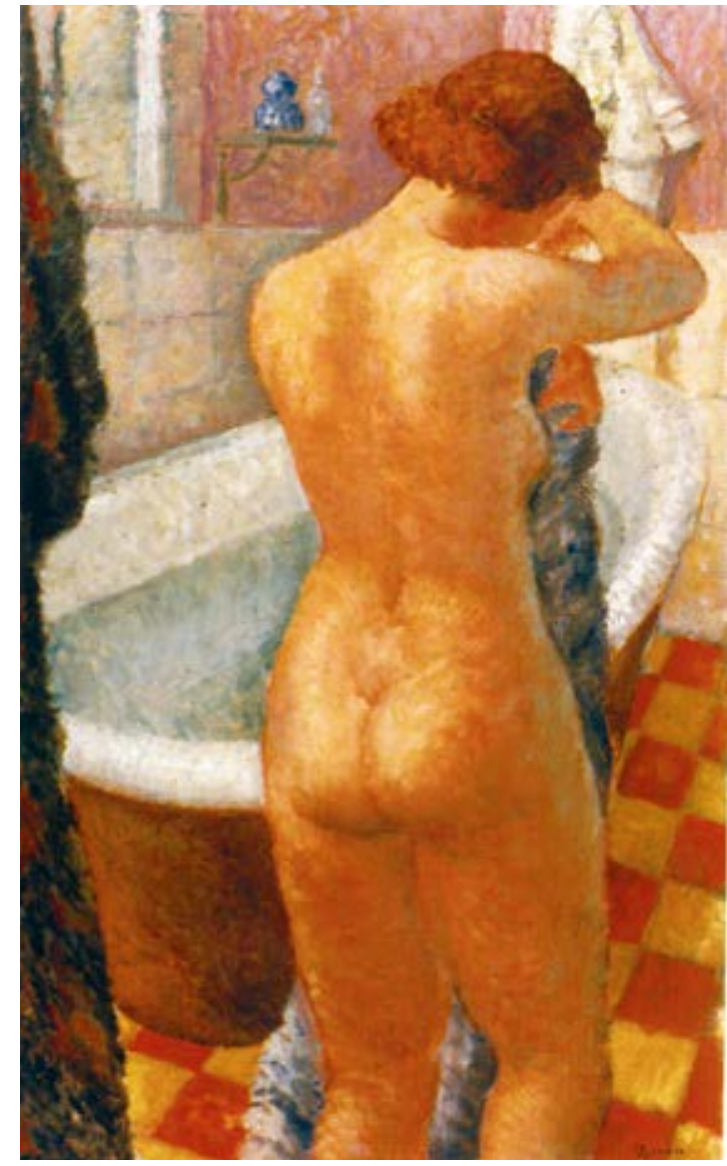

3.

Tymon Niesiołowski, Nude of a Standing Woman, 1936, canvas, oil, Lithuanian National Museum of Art, Vilnius

Tymonas Niesiołowskis, Stovinčios moters aktas, 1936

in a refugee camp in Pruszkow. Mieczysław Wallis writes: "When, finally, in January 1945, liberation came, Kuna was already seriously and hopelessly ill. Until that moment, he still entertained himself with the hope that his beloved son was alive. The news, which left no doubt about the tragic fate of his son, was a heavy blow for the artist and significantly worsened his state of health. Appointed as Professor of Sculpture at the Department of Fine Arts of Nicolaus Copernicus University in Torun, he sought to move to this city as soon as possible" ${ }^{10}$. On 13 October, Tymon Niesiołowski, taking every precaution, brought him by boat from Warsaw to Torún. Here Kuna still survived several happy days when he felt a surge of strength and dreamed 
of returning to creative and pedagogical work. Niesiołowski recalls: "He still wanted to work, thought about making contact with the youth, was worried about whether he would get a good enough workshop for working with students. Kuna said: 'The art of sculpture must be fully delivered in the free Poland""11.

\section{Tymon Niesiołowski in Vilnius in the years 1926-1939}

However, let us return to the "free Poland" of the 1930 s, to the "Polish Vilnius" of the interwar period, to see what the role of Kuna and Niesiołowski is in the artistic life of this city.

Their work, as well as their pedagogical activities at the Department of Fine Arts of Stephen Báthory University, contributed to a kind of "late revival of the avant-garde", and with this to renewal of the entire Vilnius Art School, which combined the classical traditions laid down by Ferdynand Ruszczyc and his followers with the new trends of modern art, formed under the influence of Paris and other centres of European art culture.

Neither Niesiołowski nor Kuna were natives of Vilnius (Niesiołowski came to Vilnius from Zakopane, Kuna, although working in Vilnius, remained a resident of Warsaw), and the process of their organic "entry" into the culture of Vilnius, the acceptance of their works by the Vilnius public, including its conservative circles, was neither simple nor easy. This is evidenced by the dramatic fate of the unrealised project of the monument to Adam Mickiewicz, created by Kuna, which we will return to later. I would like to start with the personality of Tymon Niesiołowski.

He arrived in Vilnius in 1926, in 1926-1932 he worked here as the director of the School of Art Crafts, and from 1928 he taught at Stephen Báthory University, as assistant professor. In 1939 he was appointed to a full professorship, but this appointment did not actually take place due to the beginning of the war ${ }^{12}$. He enjoyed the fame of a progressive painter and at the 1937 International Exhibition in Paris he was awarded the Silver Medal.

His work brought a fresh stream to Vilnius painting. This was striking from the very first steps of Niesiołowski's creative activity in Vilnius. Stefania Zakhorska in her review of the exhibition organised by the Vilnius 
Association of Artists (Wileńskie Towarzystwo Artystów Plastyków), in which Niesiołowski participated, wrote: "Against the background of this coloristic anaesthesia, Tymon Niesiołowski's paintings make a reviving impression. Niesiołowski is a painter, and already from this elementary statement of fact, it blows with joy. Tymon feels colour and feels paint"13. [illus. 7, 8]. Her use of the word "anaesthesia" refers to the complete insensibility to colour, the absence of a colouristic culture, which were striking in the works of Ludomir Sleńdziński, his students and followers. The art historian M. Sterling emphasised: "Among the mass of Vilnius painters, this tireless seeker of the new is one of the most interesting figures. He has brought a new breath to the artistic life of Vilnius and not only Vilnius"14. The artist M. Kulesza claims: "Tymon has a special place in the art of Vilnius. He consistently implements his ideas and artistic credo"15.

The significance of the creative personality of Niesiołowski was visible not only in Vilnius and Poland, but also in distant Moscow, where the outstanding master of graphic arts and contemporary art connoisseur, Alexey Kravchenko, in his review of the exhibition of Polish art organised by the Society for Cultural Relations of the USSR with Foreign Countries, highlighted Niesiołowski's paintings as "the best pictures", and wrote: "Niesiołowski is the most typical and prominent master of the modernist direction. His canvases amaze with the power and expressiveness of colour"16. I can add to this that my father, Michał Czerwonny, who then worked as the Head of the Department of Foreign Exhibitions of the Society for Cultural Relations of the USSR with Foreign Countries, took part in organising this exhibition in November 1933 and was very impressed by Niesiołowski's painting.

The presence of Niesiołowski in Vilnius, his creative and pedagogical activities were of great importance for the culture of the city. But Niesiołowski's life in Vilnius was not an idyllic pastoral. True, his career in Vilnius before the outbreak of World War II, in any case from a formal point

13 Stefania Zahorska, "Wystawa Wileńskiego Towarzystwa Plastyków w Zachęcie" [The exhibition of Tymon Niesiołowski in Zachęta], in: Wiek XX, No. 2, 1928, pp. 4-5; from Małgorzata Gieroń, op. cit., p. 33.

14 Mieczysław Sterling, Wystawa zbiorowa Tymona Niesiołowskiego (Review exhibition of Tymon Niesiołowski), [Warszawa]: Instytut Propagandy Sztuki, 1935, pp. 6-7.

15 Marian Kulesza, "Wystawa Jubileuszowa WTAP" [Anniversary exhibition of the Vilnius Artists' Association], in: Kurier Wilenski, No. 131, 1930, p. 7.

16 Алексей (А. Е.) Кравченко, “Современное польское искусство. Лучшие полотна” [The modern Polish Art. The best painting], in: Советское искусство, No. 17, 1933, p. 3. 


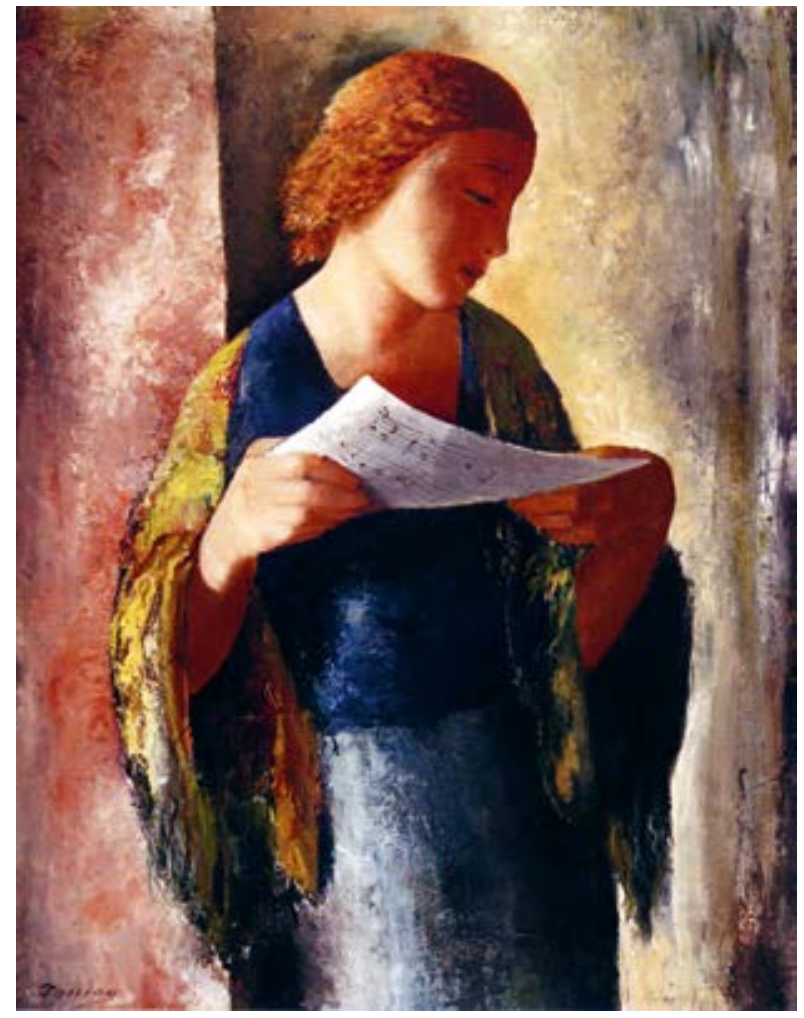

4.

Tymon Niesiołowski, Female Singer, 1932, canvas, oil, Private collection

Tymonas Niesiołowskis, Dainininke, 1932

of view, developed successfully - participation in exhibitions, promotion at the University, popularity among students... ${ }^{17}$ But the artist did not feel that Vilnius was his home. He did not turn a blind eye to the imperfection (moral and professional) of all that could be called the Vilnius Art School of the interwar period. In this context, his Memoirs, published after the war, remain the most important source for studying the cultural atmosphere of pre-war Vilnius. A taste of bitterness and disappointment is felt in many of his notes regarding the behaviour of his colleagues and the general situation at the Department of Fine Arts of SBU.

17 „At first I taught at the School of Art Crafts, managed to get support for this school and funds from the Education Ministry. Every day I visited the offices of officials, wrote statements and programmes. Finally, I became a teacher at this school and caused extreme irritation to my fellow painters. Two years later, with the assistance of Ludomir Sleńdziński, I became an assistant at the University of Stephen Báthory, then received the title of assistant professor, led a painting workshop there and gave lectures on didactics of drawing, and also taught painting technology and the basics of decorative painting. Murals and other monumental paintings by my students appeared in the corridors" (Tymon Niesiołowski, pp. 112-113). 


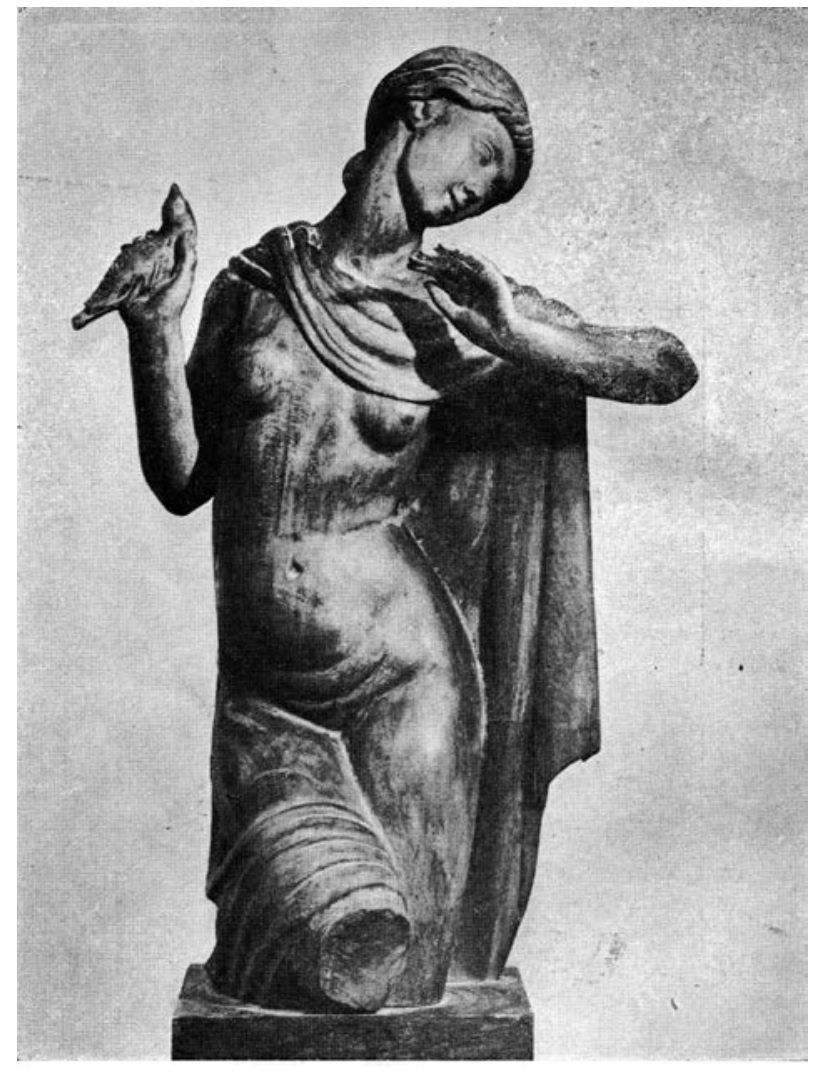

5.

Henryk Kuna, Woman with a Bird, 1930s, wood, National Museum in Warsaw

Henrykas Kuna, Moteris su paukščiu, XX a. 4 deš.

In Memoirs Niesiołowski writes: "Providence has now ordered me to adjust to the new environment in Vilnius. New acquaintances, far from friendship. At the University, new aliens set the tone. Local 'Mughals' with an oblique look looked at those "who came here to teach us"'18.

He could not come to terms with the moods and manifestations of anti-Semitism that penetrated the university's teaching staff. He writes: "At the University, I had to categorically insist that five Jews, my students, have the right to attend my classes. An unhealthy and unconstructive aura reigned in our school"19. Coming from the mouth of Niesiołowski, this anti-Semitism would surprise Poles of today who are so proud of the enormous value and outstanding importance of Stephen Báthory University, and who in 2019 are enjoying the festive celebrations on the occasion of university 


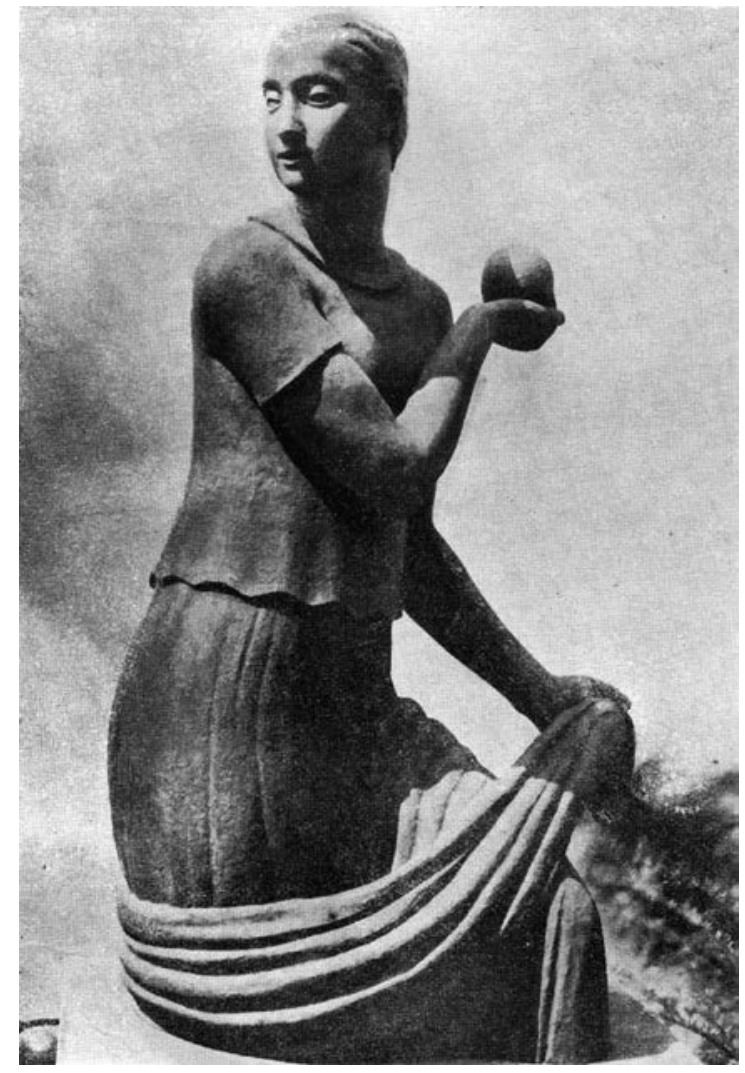

6.

Henryk Kuna, Atalanta, 1930 s, bronze, National Museum in Warsaw

Henrykas Kuna, Atalanta, $\mathrm{XX}$ a. 4 deš.

100th anniversary. Meanwhile, criticisms of the university, its teachers and some aspects of its activity can also be found in other publications - in the testimonies of people who studied and worked at this university and whom it is hard to blame for the lack of Polish patriotism ${ }^{20}$. It seems that in assessing this school more balanced caution is needed and, so to speak, "a sense of historical context", "sense of time". When the fate of the university was threatened, on the eve of its liquidation - on 15 December 1939 - the same Niesiołowski who soberly and critically assessed the negative aspects of the aura that dominated this school, together with the entire Polish intelligentsia of Vilnius, defended the university. He signed a protest from teachers who stated: "The Lithuanian government, by eliminating the Polish university in Vilnius, destroys a Polish cultural institution of high scientific

20 See, for example, the book: Wiktor Sukiennicki, Legenda i rzeczywistość, Wspomnienia i uwagi o dwudziestu latach Uniwersytetu Stefana Batorego w Wilnie [Legend and reality. Memoirs and remarks about twenty years of the Stephen Báthory University in Vilnius], Paryż: Instytut literacki, 1967. 
importance"21. This protest, together with teachers from other faculties, was signed by Jerzy Hoppen, "Associate Professor of the Department of Fine Arts" and "Tymon Niesiołowski, Department of the Arts"22.

The underestimation of this university, ignoring its contribution, in particular, the contribution of the Department of Fine Arts, to the culture of Vilnius, and thereby to the history of Lithuanian art, lie on the conscience of the entire Lithuanian humanitarian science of the war- and post-war period. However, the idealisation of this university, in particular the idealisation of the Department of Fine Arts, the lack of will in recognising and revealing the dark sides of the "sanitation" regime, the shadow of which also fell on Stephen Báthory University, still remain an overwhelming weakness of Polish humanities. Nevertheless, the search for a true and objective assessment of this school is moving forward on both sides of the Polish-Lithuanian border. In Lithuanian scientific literature, the most important successes along this path were marked by the publication of the first, fundamental monograph Ferdynand Ruszczyc ${ }^{23}$ and by the publication of the exhibition catalogue (In)visible Vilnius: Shapes of interwar Art and Architecture ${ }^{24}$ in Lithuanian. On the other hand, in Polish art criticism there have long been critical assessments of the "Vilnius school" of the interwar period. I will quote in this connection an article by Janusz Bogucki on the work of Niesiołowski:

\footnotetext{
The very existence of the 'Vilnius school' created a kind of provincial academism in the 1930s. Its main creator and leader, Ludomir Sleńdziński, was undoubtedly an outstanding personality, and in the years of his youth he was an observant, lively, impressionable artist. He belonged to the category of European painters who tried to connect certain achievements of modern art (primarily post-cubist geometrisation) with an eclectic return to the conventions of the old times (Middle Ages, the
}

21 Quoted from: Ostatnie dni Uniwersytetu Stefana Batorego. Świadectwo dokumentalne, zebrał i wstępem opatrzył Piotr Łossowski [The last days of the Stephen Báthory University. Documentary evidence], Ed. Piotr Łossowski, Warszawa: Uniwersytet Warszawski, Wydział Dziennikarstwa i Nauk Politycznych, 2012, p. 65.

22 Ibid., p. 71.

23 Algè Andriulytė, Ferdynandas Ruszcycas, Civis Vilnensis Sum, Vilnius: Vilniaus dailès akademijos leidykla, 2018.

24 (Ne)matomas Vilnius: tarpukario dailès ir architektūros pavidalai: Parodos katalogas, Vytauto Kasiulio dailès muziejus, 2018 m. liepos 12 d. - rugsẻjo 16 d. / (In)visible Vilnius: Shapes of interwar Art and Architecture: Exhibition catalogue, Ed. Algė Andriulytė, Rasa Butvilaitė, Ilona Mažeikienè, Vilnius: Vilniaus dailès akademijos leidykla, 2018. 


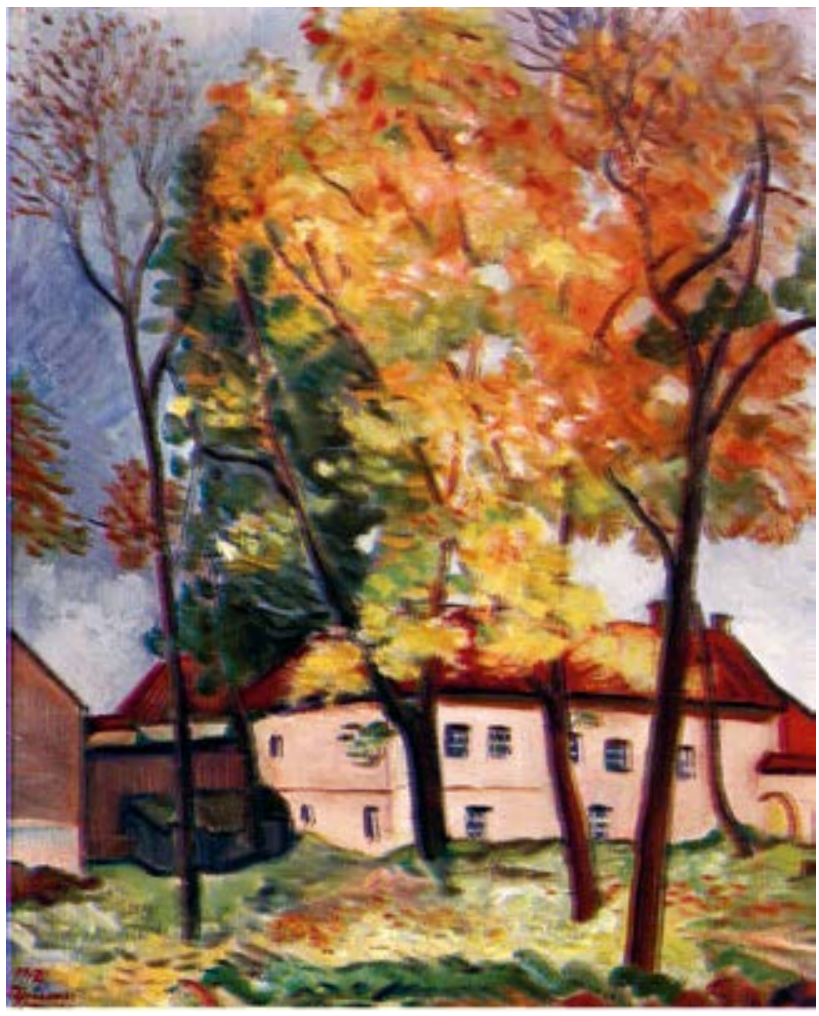

Tymon Niesiołowski, Vilnius Landscape, 1942, canvas, oil, Regional Museum in Suwalki

Tymonas Niesiołowskis, Vilniaus peizažas, 1942

Renaissance, 17th century Dutch painting) As he grew older and became an influential man, surrounded by artists who imitated him, Sleńdziński lost interest in the discoveries of modern art and devoted all his hardworking talent to the reconstruction of museum values and the perfection of craftsmanship, partially linking these tasks with the development of contemporary themes. So gradually formed that tough and pedantic 'classicism', which was the main artistic manner of the Maestro and his followers. Jamontt and Hoppen were not literally followers of this manner. Separating in principle the historicism and eclecticism of Sleńdziński, they can be said to represent romantic deviations from his doctrine. Jamontt, with his love for the restless clouds of heaven, tall trees and rickety houses, seems to have also owed his romanticism to Ruszczyc. Hoppen, brilliantly imitating the technique, and sometimes the theme of 17th century Dutch engravings (their architectural 

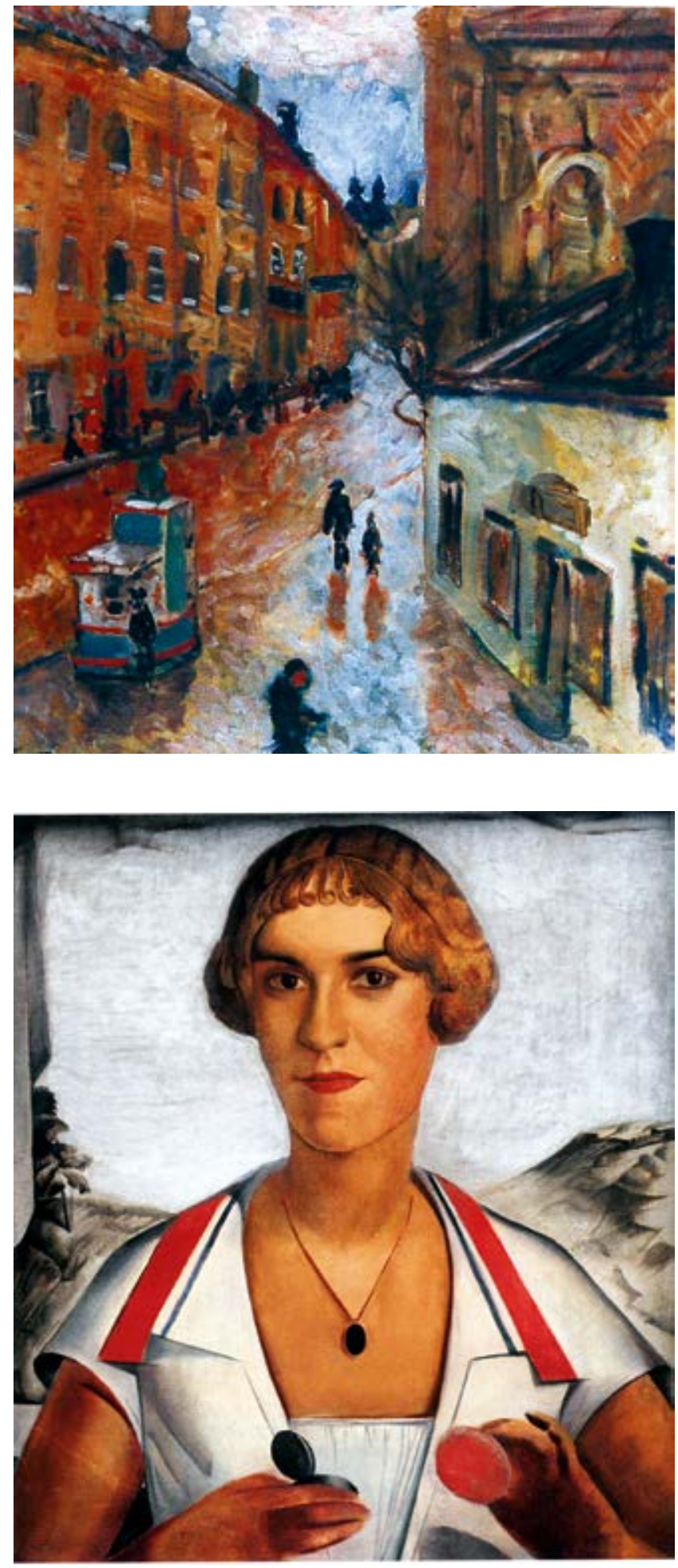

8.

Tymon Niesiołowski, Vilnius, 1936, canvas, oil, Regional Leon

Wyczolkowski Museum in Bydgoszcz

Tymonas Niesiołowskis, Vilnius, 1936
9.

Ludomir Sleńdziński, Portrait of Woman, 1925, canvas, oil, Lithuanian National Museum of Art, Vilnius

Ludomiras Sleńdzińskis, Moters portretas, 1925 
motives), was sure that the development of true art in Europe ended in the 18th century $<\ldots>$ Kuchinsky, continuing stylisation in woodcuts, represented eclecticism, not as fundamental as that of Hoppen, but also academic. On the whole, Jamontt, Hoppen and Kuchinsky are old-fashioned artists who, however, possess a great culture and a deep knowledge of the originals. These are masters of romantic, provincial academism, anachronistic, and not banal figures in the art of the 20th century. ${ }^{25}$

It is clear what a strong impression Niesiołowski's painting had on this background, how noticeably it differed from the "Vilnius school" of Sleńdziński [illus. 9].

\section{The fate of the monument to Adam Mickiewicz}

Significant changes occurred in the 1930s at the department (chair) of sculpture. Previously, under the leadership of Bolesław Balzukevich, it was guided by academics and was far from being innovative in world sculpture. Once Henryk Kuna, who was appointed Professor at Stephen Báthory University (1936) took over the department, the curriculum of this department began to change, opening up new opportunities for young sculptors to identify their creative personality in different directions of modernity.

When Kuna held the chair of sculpture at the Department of Fine Arts at Stephen Báthory University, he was already recognised as a master. He was known in Poland and abroad; his works were exhibited in museums in Warsaw, Paris, London and were famous in America; at the International Exhibition in Paris (1937), he received the Grand Prix; at the exhibition in Padua, he received a gold medal for sculptural works of religious content. According to M. Wallis, it was not by chance that Kuna decided to participate in the competition for a monument to Adam Mickiewicz for Vilnius. "He began this work with incredible enthusiasm" ${ }^{26}$. In 1932, the jury of the competition, which included the sculptor Tadeusz Breyer, the painter Ludomir Sleńdziński, two architects (Marian Lalewicz and Adolf Szyszko-Bohusz)

25 Janusz Bogucki, "Działalność Tymona Niesiołowskiego na tle życia artystycznego Torunia w latach 1945-1960" [The activity of Tymon Niesiolowski in the background of the Torun art life in the years 1945-1956], in: Bydgoski Rocznik Muzealny I, Materiaty sesji naukowej "Tymon Niesiołowski a sztuka jego czasów”, 24-25 II 1967, Bydgoszcz: Muzeum im. Leona Wyczółkowskiego, 1967, pp. 117-118.

26 Mieczysław Wallis, op. cit., p. 24. 


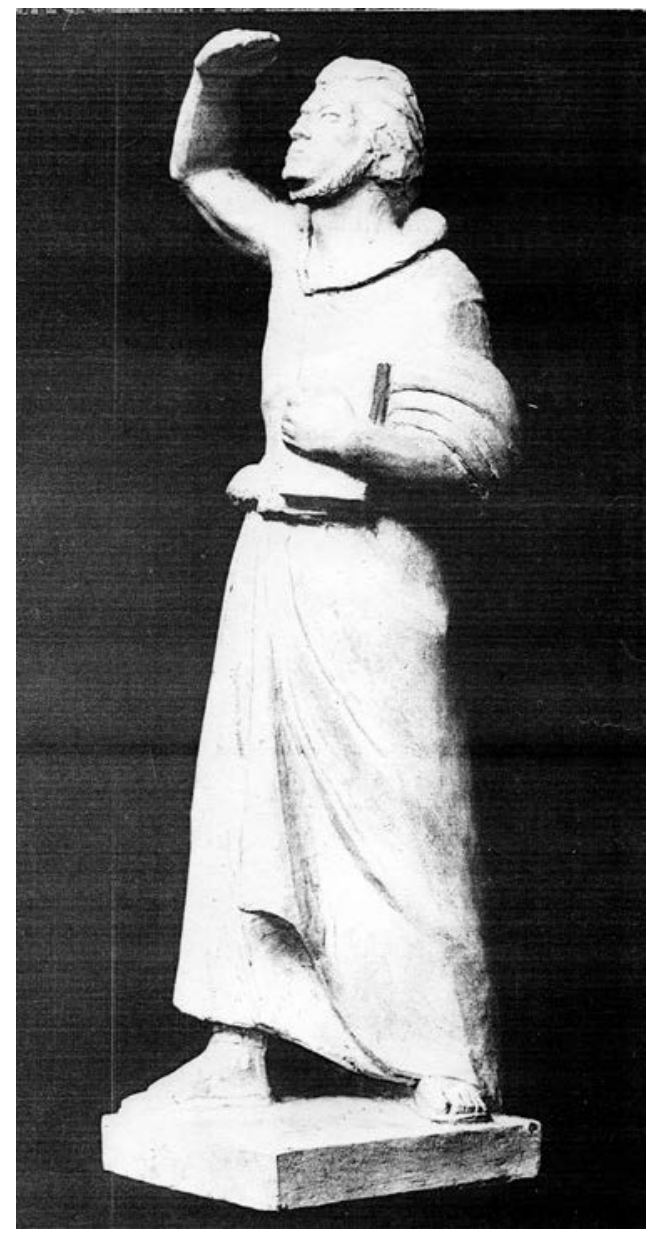

10.

Henryk Kuna, Adam Mickiewicz, Model of the statue for the monument in Vilnius, 1931-1939, patinated Plaster, National Museum in Warsaw

Henrykas Kuna, Adomas Mickevičius, paminklo Vilniuje skulptūrinis modelis, 1931-1939

and two art historians (Juliusz Kłos and Stanisław Lorentz), awarded the first prize to Kuna's project (among other participants in the competition were such great masters as Ksawery Dunikowski). Kuna's project was a full-length standing figure of the poet, cast in bronze, mounted on a high base - a pillar reminiscent of the famous statue of the pagan Slavic Svyatovid with a capital in the feed of four face masks. On a high pillar-base there were relief compositions located in three tiers carved in granite. The total height of the monument was 17 meters; the figure of the poet was 6 meters high. In the image of Kuna, Mickiewicz is holding a book to his chest with 
his left hand, and holding his right hand above his head, as if covering his face from too much sunlight. Kuna portrayed Mickiewicz in old style clothes (cloak, sandals) [illus. 10].

In the reliefs, the sculptor presented scenes from the poem Dziady (Forefather's Eve). Four of the ten reliefs represented scenes from the second part of the poem: laying of wreaths on the graves; the guslar calling for participation in the rite (to the words of the poem "Ciemno wszędzie, głucho wszędzie..." (It is dark, it is dull everywhere...); the ghost of an evil master (to the words "Hej, sowy, puchacze, kruki!..” (Hey owls, crows!..)); the guslar shows the ghost a cross (to the words "Darmo proszę, darmo gromię, On się przekleństwa nie boi" (I ask in vain. He is not afraid of a curse...); [illus. 11]. The six remaining reliefs represent scenes from the third part of the poem: the chamber of Conrad; Priest Piotr casts out an evil spirit; Rollisonowa, Kmitowa and priest Piotr visit Senator Novosiltsev; Conrad's meeting with the priest Piotr, who was summoned to investigate; the guslar at a cemetery shows a ghost to a woman in mourning clothes; road to exile. The individual programme itself, the choice of scenes for these reliefs force to viewer to reflect deeply. Their plastic interpretation is very expressive. Composite rhythms, as well as accents placed on dramatic gestures and movements of the characters, determine the character of Kuna's sculpture. These reliefs occupy an important place among all of Kuna's works. They are created with an inspiration that corresponds to the high spirit of Mickiewicz's poetry. Admiration for poetry and the desire to create a monumental work worthy of the poet's memory, inscribed in the city landscape, all contributed to the fact that Kuna worked on this project with great inspiration and invested all his soul and talent, his artistry and creative experience in it. The work progressed rapidly. Already in October 1932, the sculptor had submitted to the Committee for the construction of the monument a plaster model of the poet's statue $180 \mathrm{~cm}$ high, as well as the first reliefs made in clay. That winter, he continued to sculpt reliefs and cast them in plaster. In August 1933, work on a large wooden model of the statue was close to completion. All the reliefs were cast in plaster and work began on their embodiment in rose Volyn granite. It was planned to unveil the monument in June $1935^{27}$. 
This did not happen in 1935 or in subsequent years, and World War II was not the main fault or reason here, as authors of post-war publications often emphasised, trying to shift all responsibility to the German occupiers. It was not the Germans, but the Poles of Vilnius who were not allowed to build this monument. Representatives of the reactionary circles of Vilnius society blinded by nationalism could not come to terms with the fact that a monument to the great Polish poet would be erected in the centre of the city by a man who in their eyes, was denied the right to be a Pole because of his Jewish origin. A hideous campaign was launched against the artist. Kuna, being an impressionable and delicate person, besides already suffering from heart disease, did not have the strength to fight. The famous painter Ferdynand Ruszczyc, the graphic artist Jerzy Hoppen, the architect Stefan Narębski, the members of the Council, uniting all Vilnius art organisations, all defended the Kuna project of the Mickiewicz monument, but their efforts were in vain. The reactionaries insisted. their campaign was a success.

However, a trace from this monument remained in Vilnius, and what a magnificent trace! - Almost all the granite reliefs survived the war. And for this we must be grateful to the new owners of the city - the Lithuanians, who in 1939 returned to their historic capital.

In September 1939, a model of the statue, cast in bronze, was in the bronze workshops of Kranz \& Łempicki in Warsaw. One of the first bombs dropped by the Germans on Warsaw fell there. The wooden model of the statue burned down. In November 1939, the invaders smashed the bronze statue into pieces and melted down the pieces for weapons. Only the gypsum model of the statue survived (after World War II, it ended up in the National Museum in Warsaw). Granite relief plates with images of scenes from the poem Dziady (Forefather's Eve) have also been preserved. One of these granite slabs, which suffered during the Warsaw Uprising, is now located in Wilanow, the rest - in Vilnius. They were found after the war in the basements of the former Bernardine Monastery, which housed the Vilnius Academy of Arts / Art Institute of the Lithuanian SSR (before the war - the Department of Fine Arts of Stephen Báthory University). It was decided to preserve these granite slabs at an "open-air exhibition", in the square 


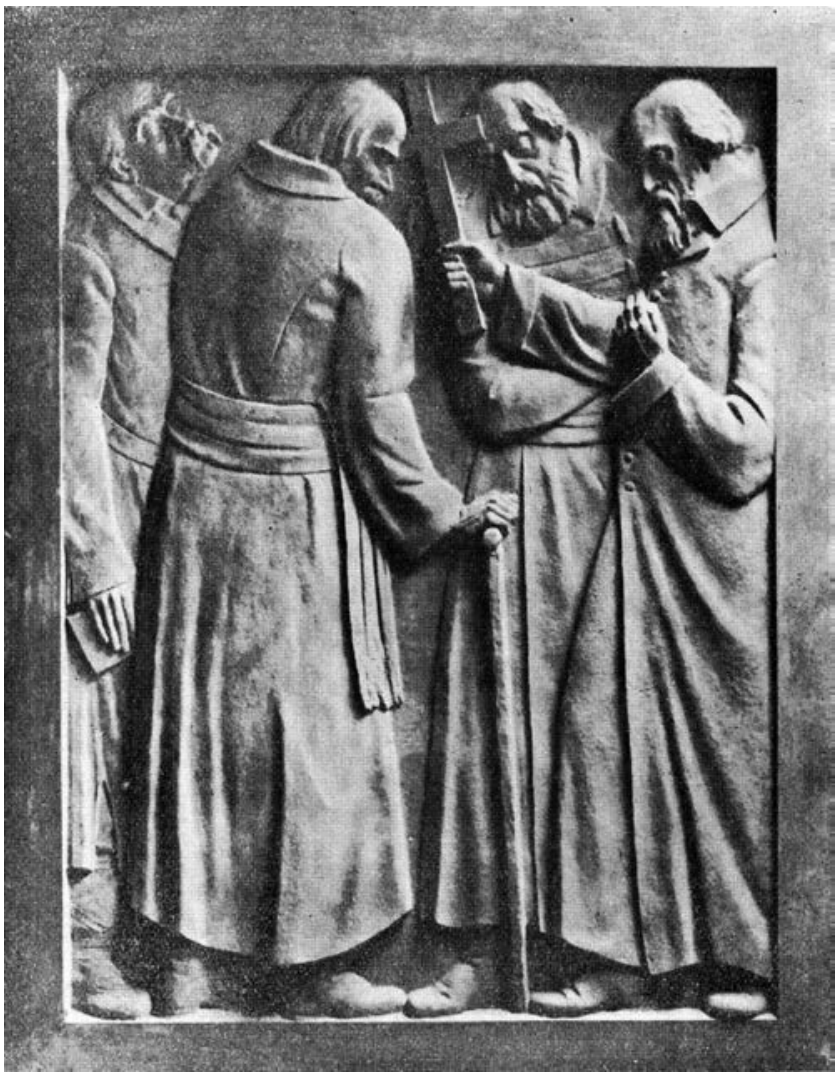

11.

Henryk Kuna, Forefather's Eve (Dziady), One of the bas-reliefs intended for the foundation of the monument to Adam Mickiewicz in Vilnius, 1939

Henrykas Kuna, Vèlinès (Dziady), vienas iš Adamo Mickiewicziaus paminklo Vilniuje fundamentui skirtu bareljefų, 1939

in front of the entrance to the building of the Art Institute. The sculptor Juozas Mikènas, who was then the head of the sculpture department of the institute played a decisive role in this decision. They lay in this place, right under the windows of the sculpture workshops, for almost three decades from the mid-1950s to the mid-1980s. Students of the Vilnius Art School of the second half of the 20th century, daily communicating with these works and seeing them before their own eyes, naturally became guardians of those ideals and successors of those traditions that went back both to sculpture (to Kuna's work) of the pre-war period and to the romanticism of Polish poetry of the 19th century (Dziady / Forefather's Eve for Lithuanian youth of the 1960s and 70s meant no less than for Polish spectators of this time). 
The continuation of this history was the construction of the monument to Mickiewicz in Vilnius, which was unveiled on 18 April 1984. Its author was the famous Lithuanian sculptor, a student of Juozas Mikenas, Gediminas Jokūbonis. His original project is neither an imitation, nor a repetition of Kuna's project. However, he decided to include granite slabs with Kuna's reliefs in the spatial concept of his monument. Thus, different periods and traditions of Vilnius art culture were united with each other.

Conflicts and contradictions in the artistic life of the pre-war period indicate that the culture of "Polish Vilnius" was not a homogeneous phenomenon. It had various flanks, directions, and it was not easy for it to cope with the problems of mastering that what was new or seemed unusual or alien.

\section{Submitted - 06/01/2020}




\section{Bibliography}

Anders Henryk, Rytm. W poszukiwaniu stylu narodowego [Rhythm. Looking for a national style], Warszawa, 1972.

Andriulytè Algè, Ferdynandas Ruszcycas, Civis Vilnensis Sum, Vilnius: Vilniaus dailès akademijos leidykla, 2018.

Bogucki Janusz, "Działalność Tymona Niesiołowskiego na tle życia artystycznego Torunia w latach 1945-1960" [The activity of Tymon Niesiolowski on the bachground of the Torun art life in the years 1945-1956], in: Bydgoski Rocznik Muzealny I, Materiaty sesji naukowej "Tymon Niesiołowski a sztuka jego czasów”, 24-25 II 1967, Bydgoszcz: Muzeum im. Leona Wyczółkowskiego, 1967, pp. 108-131.

[Czerwonnaja Swetlana], Червонная Светлана, Микенас [Mikènas], Ленинград: издательство «Искусство», 1963.

George Waldemar, Galdikas, Paris: Edition Arts et Lettres, 1931.

Gieroń Małgorzata, "Kalendarium życia i twórczości Tymona Niesiołowskiego" [Calendar of the life abd creativity of Tymon Niesiołowski], in: Tymon Niesiołowski (1882-1965): Katalog wystawy monograficznej [Tymon Niesiołowski (1882-1965): The catalogue of the personal exhibition], Ed. Agata Rissman, Toruń: Muzeum Okręgowy, 2005, pp. 13-54.

Koper Stanisław, Piekietko nad Wista, Sceny z życia polskich elit pod okupacja [A little hell over the Vistula. Scenes from the life of Polish elites under occupation], Warszawa: Bellona, 2019.

[Kravchenko Aleksey] Кравченко А. Е., “Современное польское искусство. Лучшие полотна" [The modern Polish Art. The best painting], in: Советское искусство, No. 17, 1933, p. 3.

Kulesza Marian, "Wystawa Jubileuszowa WTAP" [Anniversary exhibition of the Vilnius Artists' Association], in: Kurier Wileński, No. 131, 1930, p. 7.

(Ne)matomas Vilnius: tarpukario dailes ir architektūros pavidalai: Parodos katalogas, Vytauto Kasiulio dailès muziejus, $2018 \mathrm{~m}$. liepos $12 \mathrm{~d}$. - rugsèjo $16 \mathrm{~d}$. /

(In) visible Vilnius: Shapes of interwar Art and Architecture: Exhibition catalogue, Ed. Algè Andriulytè, Rasa Butvilaitè, Ilona Mažeikienè, Vilnius: Vilniaus dailès akademijos leidykla, 2018.

Niesiołowski Tymon, Wspomnienia, Warszawa: Czytelnik, 1963.

Ostatnie dni Uniwersytetu Stefana Batorego. Świadectwo dokumentalne, zebrał i wstępem opatrzył P. Łossowski [The last days of the Stephen Báthory University. Dokumentary evedence], Ed. Piotr Łossowski, Warszawa: Uniwersytet Warszawski, Wydział Dziennikarstwa i Nauk Politycznych, 2012.

Sterling Mieczysław, Wystawa zbiorowa Tymona Niesiołowskiego [Review exhibition of Tymon Niesiołowski], [Warszawa]: Instytut Propagandy Sztuki, 1935.

Sukiennicki Wiktor, Legenda i rzeczywistość, Wspomnienia i uwagi o dwudziestu latach Uniwersytetu Stefana Batorego w Wilnie [Legend and reality. Memoirs and remarks about 20 years of the Stephen Báthory University in Vilnius], Paryż: Instytut literacki, 1967.

Tymon Niesiołowski (1882-1965): Katalog wystawy monograficznej [Tymon Niesiołowski (1882-1965): The catalogue of the personal exhibition], Ed. Agata Rissman, Toruń: Muzeum Okręgowy, 2005.

Wallis Mieczysław, Henryk Kuna, Warszawa: Wydawnictwo Arkady, 1959.

Wystawa rzeźb Henryka Kuny 1879-1945, Wrzesień-październik 1956 [The Exhibition of Henryk Kuna's sculpture. SeptemberOctober 1956], (Katalog opracował Dariusz Kaczmarek, autor artykułu wstępnego Mieczysław Wallis / Ed. Dariusz Kaczmarek, Mieczysław Wallis - author of the introductory article), [Warszawa]: Związek Polskich Artystów Plastyków, Centralne biuro wystaw artystycznych, [1956].

Zahorska Stefania, "Wystawa Wileńskiego Towarzystwa Plastyków w Zachęcie” [The exhibitoon of Tymon Niesiołowski in Zachęta], in: Wiek XX, No. 2, 1928, pp. 3-7.

Żyznowski Jan, "Zachęta. Wystawa Rytmu” [Zahęta. The Exhibition of Rhythm], in: Wiadomości literackie, No. 21, 1924, pp. 5-7. 


\title{
Henrykas Kuna ir Tymonas Niesiołowskis: naujos kryptys $X X$ a. 4 deš. Vilniaus mene
}

\author{
Swietłana Czerwonnaja
}

Reikšminiai žodžiai: Vilniaus meno mokykla, pavèluotas XX a. 4 deš. avangardas, meninio gyvenimo (lenkiškajame) Vilniuje ir Kaune palyginimas.

Tapytoją Tymoną Niesiołowski (1882-1965) ir skulptorių Henryką Kuną (1879-1945) būtų galima laikyti ryškiausiomis asmenybėmis XX a. 4 deš. Vilniaus meno scenoje. Jie buvo susiję tiek kūrybinio bendradarbiavimo, tiek ir asmeninės draugystès ryšiais (būtent Niesiołowskis 1945 m. pervežè jau mirtinai sergantị Kuną i Torunę, kur jie kartu dalyvavo Dailès fakulteto atidaryme naujai įkurtame Mikalojaus Koperniko universitete). Jų kūryba bei pedagoginè veikla Stepono Batoro universiteto Dailès fakultete prisidėjo prie savotiško XX a. 4 deš. Vilniaus mene įvykusio pavèluoto avangardinio meno atgimimo. Ju veikla paskatino atsinaujinti visą Vilniaus meno mokyklą, kuri jungè klasikines Ferdynando Ruszczyco ir jo sekejjų propaguotas tradicijas su Paryžiaus bei kituose Europos meno centruose vystytomis šiuolaikinio meno tendencijomis ir kryptimis. Niesiołowskis buvo žinomas kaip progresyvus menininkas (jaunysteje jis bendradarbiavo su formistais ir grupe „Ritmas“) ir savo originalia kūryba inspiravo ištisą tapybos kryptį. Dailès fakulteto Skulptūros katedroje 4 deš. įvyko svarbus posūkis. Anksčiau, vadovaujant Bolesławui Balzukiewicziui, katedroje vyravo akademizmas ir inovatyviomis kryptimis net nekvepèjo. Tačiau paskyrus Kuną ypatinguoju profesoriumi ir jam perèmus Skulptūros katedros vadovo pareigas, edukacinė programa ėmè keistis. Tai leido jauniesiems skulptoriams identifikuoti savo kūrybą su ịvairiomis moderniosios plastikos kryptimis. Nei Niesiołowskis, nei Kuna nepriklausè vietiniam Vilniaus menininkų ratui (Niesiołowskis ị Vilnių iš Zakopanės atvyko 1926 m., o Vilniuje dirbęs Kuna tebegyveno Varšuvoje), tad jų asimiliacija Vilniaus kultūroje, ypač 
konservatyvesniuose jos ratuose, anaiptol nebuvo lengva ir paprasta. Be kitu dalykų, tą iliustruoja dramatiška Adamui Mickiewicziui skirto paminklo lemtis - šis Kunos pasiūlytas projektas taip ir liko nebaigtas. Tokie konfliktai ir prieštaravimai liudija apie sudètingą lenkiškojo laikotarpio Vilniaus meninės kultūros situacija. Ši kultūrinè situacija anaiptol nebuvo vienpusè ir integrali joje reiškėsi įvairios grupės ir kryptys, o neįprastų ir vietinei sąmonei svetimu kūrinių recepcija buvo itin problemiška. 